\title{
Differential effects of genistein on apoptosis induced by fluoride and pertussis toxin in human and rat pancreatic islets and RINm5F cells
}

\author{
J Elliott, J H B Scarpello and N G Morgan \\ Cellular Pharmacology Group, School of Life Sciences, Keele University, Keele, Staffordshire ST5 5BG, UK \\ (Requests for offprints should be addressed to N G Morgan, School of Life Sciences, Huxley Building, Keele University, Keele, Staffordshire ST5 5BG, UK; \\ Email:n.g.morgan@keele.ac.uk)
}

\begin{abstract}
Clonal pancreatic $\beta$-cell lines have been used widely for the study of the factors involved in the regulation of apoptosis but it has not been firmly established that the response of normal islets mirrors that found in transformed $\beta$-cells. In the present work, the role of pertussis toxin (Ptx)-sensitive G-proteins in the control of $\beta$-cell apoptosis was studied in isolated rat and human islets of Langerhans and compared with the clonal $\beta$-cell line, RINm5F. Annexin- $\mathrm{V}$ and deoxycarboxyfluoroscein diacetate staining was used to identify viable, apoptotic and necrotic cells directly, under fluorescence illumination. Treatment of human and rat islet cells with the G-protein activator fluoride (NaF; $5 \mathrm{mM}$ ) caused a marked increase in apoptosis that was further potentiated in islets pretreated with Ptx. The tyrosine kinase inhibitor genistein $(100 \mu \mathrm{M})$ also increased islet cell apoptosis and the combination of $100 \mu \mathrm{M}$ genistein and $5 \mathrm{mM} \mathrm{NaF}$ did not lead to any
\end{abstract}

diminution of the apoptotic response. This latter effect was quite different from that seen in RINm5F cells where the combination of $100 \mu \mathrm{M}$ genistein and $5 \mathrm{mM} \mathrm{NaF}$ resulted in much less apoptosis than was observed with either agent alone. In islets treated with a lower concentration of genistein $(25 \mu \mathrm{M}$; that did not, itself, increase cell death), the drug attenuated $\mathrm{NaF}-i n d u c e d$ apoptosis and also blocked the enhancement mediated by Ptx. These results revealed that human (and rat) islets are equipped with a Ptx-sensitive pathway that may be regulated by tyrosine phosphorylation and is anti-apoptotic. However, they also define conditions under which marked differences in response between RINm5F cells and normal islets were observed and they suggest that care should be taken when extrapolating data obtained with clonal cell lines to the situation in normal islet cells.

Journal of Endocrinology (2002) 172, 137-143

\section{Introduction}

There is mounting evidence that inappropriate activation of apoptosis plays a role in the process of $\beta$-cell loss associated with the development of type 1 and type 2 diabetes in man (reviewed by Mauricio \& MandrupPoulsen 1998, Signore et al. 1998, Sjoholm 1998, Mountz et al. 1999, Roche et al. 2000, Mandrup-Poulsen 2001). Thus, it is important that the factors involved in the regulation of $\beta$-cell apoptosis are defined and an increasing number of studies are attempting to achieve this objective. However, this can be difficult using primary human islets of Langerhans since the tissue is normally available in only limited quantity and quantitation of $\beta$-cell apoptosis is hampered by the spatial organisation of the endocrine cells within the islet structure and by the presence of other cell types. For these reasons, many workers have chosen to use cultured rodent $\beta$-cell lines as model systems for the study of the control of apoptosis (Loweth et al. 1996a, 1997, Di Matteo et al. 1997, Bai et al. 1999, Nakata et al. 1999,
Olejnicka et al. 1999, Tejedo et al. 1999, Ahmad et al. 2000, Ammendrup et al. 2000, Bonny et al. 2000, Krautheim et al. 2000, Sjoholm et al. 2000, Baker et al. 2001). The implicit assumption in such studies is that the responses observed are relevant to the aetiology of diabetes and that the cell lines respond in a similar manner to normal human islets of Langerhans. In the majority of cases, however, the validity of this conclusion has not been fully substantiated and we have shown that significant differences can exist (Loweth et al. 1996b).

One of the most widely used $\beta$-cell lines is the RINm5F cell which was originally derived from a radiation-induced $\beta$-cell tumour in the rat and has been in use for many years as a convenient source of cultured $\beta$-cells (Gazdar et al. 1980). In previous studies, we have employed RIN5mF cells to investigate the role of heterotrimeric G-protein-dependent pathways in the control of $\beta$-cell apoptosis and have shown that these cells express an anti-apoptotic pathway that is under the control of a pertussis toxin (Ptx)-sensitive G-protein (Loweth et al. 
1996a, Elliott et al. 2001). A similar pathway also exists in normal rat islets (Loweth et al. 1996a) suggesting that, at least in this respect, RINm5F cells are an appropriate model system. However, it is not known whether this mechanism is operative in human islet cells.

In recent work, we have demonstrated that the Ptxsensitive anti-apoptotic pathway present in RINm5F cells may involve the regulation of one or more tyrosine kinase enzymes (Elliott et al. 2001). In the present study, we have extended these experiments to examine the effects of the tyrosine kinase inhibitor, genistein, on cell viability in isolated human islets of Langerhans. The results reveal that significant differences exist between responses to genistein in RINm5F cells and human (and rat) islets and indicate that caution should be exercised when extrapolating from data obtained with $\beta$-cell lines.

\section{Materials and Methods}

\section{Islet isolation and culture}

Islets were isolated from Wistar rats (body weight 180 $220 \mathrm{~g}$ ) allowed free access to food and water, by collagenase digestion of the pancreas as described previously (Loweth et al. 1996a). Islets from heart-beating cadaver organ donors were isolated in the islet-transplant laboratory, University of Leicester (Leicester, UK) and transported to our laboratory in tissue culture medium (Lacey et al. 1990, 1993, Loweth et al. 1998). They were then cultured for a further 2-3 days in RPMI-1640 medium containing glucose $(11.1 \mathrm{mM})$, L-glutamine $(300 \mu \mathrm{g} / \mathrm{ml})$, sodium penicillin $\mathrm{G}(100 \mathrm{U} / \mathrm{ml})$, streptomycin sulphate $(100 \mu \mathrm{g} / \mathrm{ml})$ and $10 \%(\mathrm{v} / \mathrm{v})$ foetal bovine serum. During the culture period the islets remained free floating in the medium and did not become attached to the culture dish.

RINm5F cells were cultured in RPMI-1640 tissue culture medium supplemented with glucose $(11.1 \mathrm{mM})$, L-glutamine $(300 \mu \mathrm{g} / \mathrm{ml})$, sodium penicillin $\mathrm{G}$ (100 U/ $\mathrm{ml})$, streptomycin sulphate $(100 \mu \mathrm{g} / \mathrm{ml})$ and $10 \%$ foetal calf serum and maintained in a 95\% air:5\% $\mathrm{CO}_{2}$ atmosphere with $100 \%$ humidity at $37^{\circ} \mathrm{C}$ (Elliott et al. 2001).

Stock solutions of test reagents were prepared in dimethyl sulphoxide (DMSO) and were added directly to the culture medium, as appropriate. Control cultures received DMSO alone and the final concentration did not exceed $0 \cdot 1 \%$.

\section{Detection and quantitation of apoptosis}

Human or rat islets were treated with test reagents for the appropriate period of time then harvested by centrifugation $(600 \mathrm{~g} ; 2 \mathrm{~min})$ and washed with phosphatebuffered saline (PBS; $500 \mu \mathrm{l}$ ). They were digested with trypsin-EDTA $(100 \mu \mathrm{l})$ for $3-5 \mathrm{~min}$ until dispersed into single cells and the cells were collected by centrifugation
(1000 $g ; 3 \mathrm{~min})$. The trypsin was removed and the cells were washed twice with PBS. The cell pellet was resuspended in approximately $40 \mu \mathrm{l} \mathrm{PBS}$. In order to prevent loss of sample, the resuspended islet cells were placed inside a circle of clear varnish painted onto poly-lysinecoated slides. The slides were air dried for $10 \mathrm{~min}$ and the excess PBS removed. The samples were washed twice with $50 \mu \mathrm{l}$ binding buffer $(10 \mathrm{mM}$ Hepes, $140 \mathrm{mM} \mathrm{NaCl}$, $2.5 \mathrm{mM} \mathrm{CaCl}_{2}, \mathrm{pH} 7 \cdot 5$ ) before addition of $35 \mu \mathrm{l}$ deoxycarboxyfluoroscein diacetate together with Cy3conjugated-annexin $\mathrm{V}$ in binding buffer. The cells were then incubated for $10 \mathrm{~min}$ in the dark. The slides were washed five times with $50 \mu \mathrm{l}$ binding buffer and the numbers of viable, apoptotic and necrotic cells determined directly by cell counting under a fluorescence microscope.

In the case of RINm5F cells, they were seeded at 5000 cells per chamber in a multichamber slide and incubated overnight before treatment. The cells were treated with test reagents before the medium was removed and they were washed twice with PBS. A similar procedure for annexin-V/deoxycarboxyfluoroscein diacetate staining was used as described above for islets, except that the wash steps were increased to $200 \mu \mathrm{l}$.

\section{Materials}

The following reagents were obtained from Sigma Chemical Co. Ltd, Poole, Dorset, UK: annexin V-Cy3 apoptosis detection kit, collagenase type XI, dimethyl sulphoxide, genistein, Ptx, RPMI-1640 and sodium fluoride. Foetal bovine serum, trypsin/EDTA, L-glutamine, penicillin G and streptomycin sulphate were obtained from Gibco BRL, Paisley, Strathclyde, UK. All other reagents were of analytical grade quality.

\section{Statistics}

Differences between mean values were assessed by analysis of variance and were considered significant when $P<0 \cdot 05$. All experiments were performed in replicates of four and were repeated on at least two separate occasions.

\section{Results}

Previous studies have shown that $\mathrm{NaF}$ causes a time- and and dose-dependent loss of viability in both RINm5F cells and normal rat islets (Loweth et al. 1996a, Elliott et al. 2001). The pattern of DNA fragmentation suggested that this is mediated, at least in part, by increased apoptosis of the cells. In the present work, we have employed a more stringent analysis to identify the mode of cell death in $\mathrm{NaF}$-treated cells, by examination of annexin- $\mathrm{V}$ and carboxyfluoroscein staining under fluorescence illumination. Although time consuming, this method has the advantage that it allows the simultaneous quantitation of 


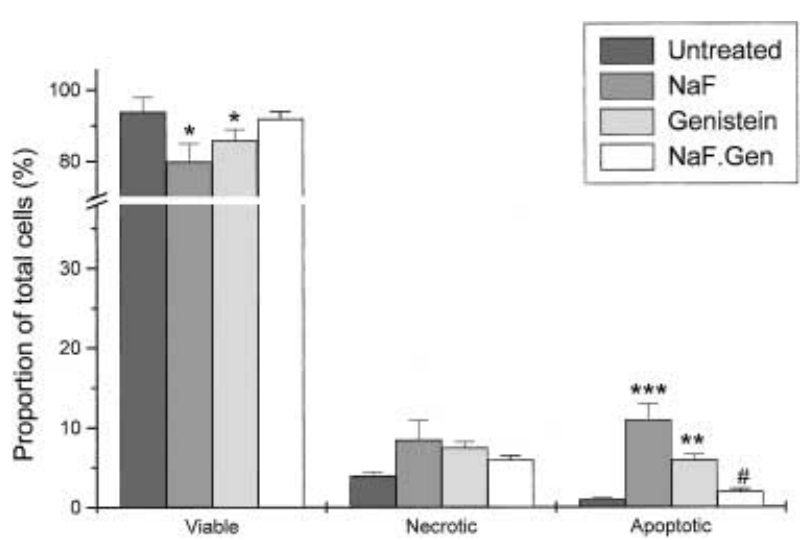

Figure 1 Effects of $5 \mathrm{mM} \mathrm{NaF}$ and $100 \mu \mathrm{M}$ genistein on cell viability in RINm5F cells. RINm5F cells were exposed to $5 \mathrm{mM}$ $\mathrm{NaF}$ or/and $100 \mu \mathrm{M}$ genistein (Gen), as shown, for $24 \mathrm{~h}$. After this time the cells were harvested and stained with annexin- $V$ and deoxycarboxyfluoroscein diacetate to reveal the number of viable, necrotic and apoptotic cells. ${ }^{*} P<0.01$ relative to untreated cells, ${ }^{* *} P<0.005$ relative to untreated cells, ${ }^{* *} P<0.001$ relative to untreated cells, $\# P<0 \cdot 01$ relative to either $\mathrm{NaF}$ or genistein alone. Values are means \pm S.E.M.

the total number of viable, necrotic and apoptotic cells under each experimental condition. Use of this technique confirmed that exposure of RINm5F cells to $5 \mathrm{mM} \mathrm{NaF}$ for $24 \mathrm{~h}$ led to a marked increase in the number of cells undergoing apoptosis (Fig. 1), whereas the number of necrotic cells was increased only marginally. Incubation of RINm5F cells with $100 \mu \mathrm{M}$ genistein (a concentration used in many previous studies of islet cell function (e.g. Sorenson et al. 1994, Jonas et al. 1995, Kwon et al. 1995, Mitchell et al. 2001) also increased apoptosis significantly (Fig. 1). Strikingly, however, incubation of RINm5F cells with both $5 \mathrm{mM} \mathrm{NaF}$ and $100 \mu \mathrm{M}$ genistein together was associated with a dramatic reduction in the extent of apoptosis such that cell viability was restored to a level similar to that seen in control cultures (Fig. 1).

In order to investigate whether a similar phenomenon occurs in primary tissue, human islets were isolated and maintained in free-floating culture in the presence or absence of $\mathrm{NaF}$ and genistein for $24 \mathrm{~h}$, prior to measurement of the extent of cell viability. As observed in RINm5F cells, exposure of human islets to either $5 \mathrm{mM}$ $\mathrm{NaF}$ or $100 \mu \mathrm{M}$ genistein alone induced a significant increase in apoptosis with little change in the number of necrotic cells. However, in marked contrast to the situation in RINm5F cells, the combination of $5 \mathrm{mM} \mathrm{NaF}$ and $100 \mu \mathrm{M}$ genistein failed to prevent apoptosis in human islets but, rather, enhanced it still further (Fig. 2).

To confirm that this effect was not related to the species difference between RINm5F cells and human islets, similar studies were repeated with isolated rat islets (Table 1). The responses observed were equivalent to those seen in human islets (but different from those in the RINm5F

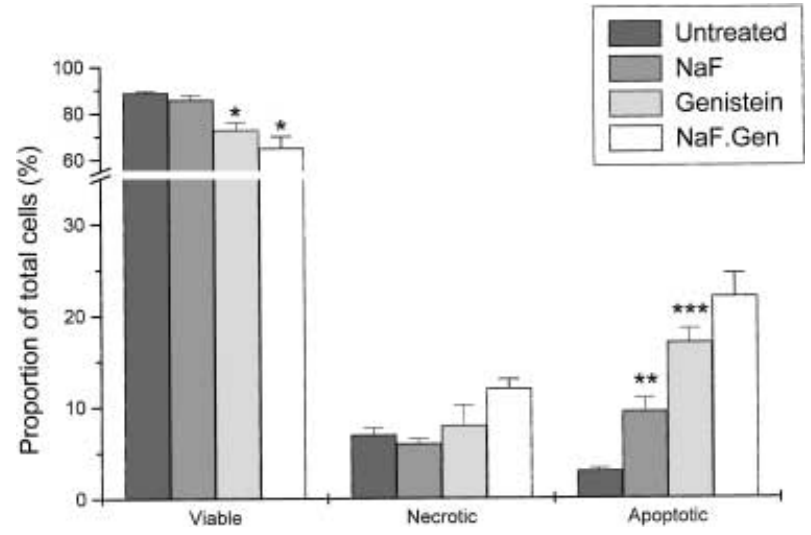

Figure 2 Effects of $5 \mathrm{mM} \mathrm{NaF}$ and $100 \mu \mathrm{M}$ genistein on the viability of human islet cells. Isolated human islets were exposed to $5 \mathrm{mM} \mathrm{NaF}$ or/and $100 \mu \mathrm{M}$ genistein (Gen), as shown, for $24 \mathrm{~h}$. After this time the islets were harvested, the cells dispersed with trypsin/EDTA and stained with annexin- $\mathrm{V}$ and deoxycarboxyfluoroscein diacetate. The number of viable, necrotic and apoptotic cells was counted and expressed as a percentage of the total. ${ }^{*} P<0 \cdot 01$ relative to untreated cells, ${ }^{* *} P<0 \cdot 005$ relative to untreated cells, ${ }^{* * *} P<0 \cdot 001$ relative to untreated cells. Values are means \pm S.E.M.

cell) in that $\mathrm{NaF}$ and genistein each caused an increase in apoptosis when added to rat islets individually and they further increased this response when used in combination (Table 1).

To clarify the situation further, an additional series of studies was undertaken in which human islets were treated with a lower concentration of genistein $(25 \mu \mathrm{M})$ in the absence and presence of $5 \mathrm{mM} \mathrm{NaF}$ (Table 2). At this concentration, previous studies have established that genistein does not significantly increase cell death in RINm5F cells, although it attenuates the increase due to $\mathrm{NaF}$ (Elliott et al. 2001). In human islets, $25 \mu \mathrm{M}$ genistein alone did not induce apoptosis but it abolished the increase mediated by $5 \mathrm{mM} \mathrm{NaF}$ (Table 2).

The experiments were then extended to compare the ability of Ptx to enhance the level of apoptosis in RINm5F cells and in normal human islets. As observed previously (Loweth et al. 1996a, Elliott et al. 2001), treatment of RINm5F cells with Ptx did not cause any direct loss of viability but the agent elicited a marked potentiation of the effect of $5 \mathrm{mM} \mathrm{NaF}$ (Fig. 3). The increase in apoptosis induced by $100 \mu \mathrm{M}$ genistein in RINm5F cells was not altered by Ptx, suggesting that different mechanisms account for the actions of $\mathrm{NaF}$ and genistein. When RINm5F cells were exposed to Ptx and then incubated with both $\mathrm{NaF}$ and genistein together, the extent of apoptosis was much less than that caused by $\mathrm{NaF}$ alone in PTX-treated cells (Fig. 3).

The responses of isolated human islets to these various incubation conditions were compared with those observed in RINm5F cells (Fig. 4) and it was revealed that, as 
Table 1 Effects of $5 \mathrm{mM} \mathrm{NaF}$ or/and $100 \mu \mathrm{M}$ genistein on the viability of rat islet cells. Values are means \pm S.E.M.

\begin{tabular}{|c|c|c|c|}
\hline & Viable & Necrotic & Apoptotic \\
\hline Untreated & $95 \pm 1$ & $1 \cdot 0 \pm 0 \cdot 2$ & $0.6 \pm 0.05$ \\
\hline $\mathrm{NaF}$ & $78 \pm 2^{*}$ & $1 \cdot 5 \pm 0 \cdot 3$ & $21 \pm 2^{\star \star}$ \\
\hline Genistein & $75 \pm 1^{*}$ & $1 \cdot 5 \pm 0 \cdot 3$ & $22 \pm 2^{* *}$ \\
\hline $\mathrm{NaF}+$ genistein & $62 \pm 3^{*}$ & $2 \cdot 5 \pm 0 \cdot 5$ & $32 \pm 3^{* * *}$ \\
\hline
\end{tabular}

Isolated rat islets were exposed to $5 \mathrm{mM} \mathrm{NaF}$ or/and $100 \mu \mathrm{M}$ genistein, as shown, for $24 \mathrm{~h}$. After this time the islets were harvested, the cells dispersed with trypsin/EDTA and stained with annexin-V and deoxycarboxyfluoroscein diacetate. The number of viable, necrotic and apoptotic cells was counted and expressed as a percentage of the total.

${ }^{*} P<0.01$ relative to untreated cells; ${ }^{* *} P<0.001$ relative to untreated cells; ${ }^{* *} P<0 \cdot 01$ relative to cells treated with NAF or genistein alone.

Table 2 Effects of $5 \mathrm{mM} \mathrm{NaF}$ or/and $25 \mu \mathrm{M}$ genistein on the viability of human islet cells. Values are means \pm S.E.M.

\begin{tabular}{|c|c|c|c|}
\hline & Viable & Necrotic & Apoptotic \\
\hline Untreated & $90 \pm 1$ & $5 \cdot 0 \pm 0 \cdot 5$ & $3 \cdot 0 \pm 0 \cdot 5$ \\
\hline $\mathrm{NaF}$ & $84 \pm 2^{*}$ & $6 \cdot 0 \pm 0 \cdot 7$ & $9 \cdot 5 \pm 1 \cdot 0^{* *}$ \\
\hline Genistein & $88 \pm 2$ & $6 \cdot 0 \pm 0 \cdot 6$ & $4 \cdot 0 \pm 0 \cdot 5$ \\
\hline $\mathrm{NaF}+$ genistein & $91 \pm 2$ & $4 \cdot 5 \pm 0.5$ & $4 \cdot 2 \pm 0 \cdot 5^{\star \star *}$ \\
\hline
\end{tabular}

Isolated human islets were exposed to $5 \mathrm{mM} \mathrm{NaF}$ or $25 \mu \mathrm{M}$ genistein, as shown, for $24 \mathrm{~h}$. After this time the islets were harvested, the cells dispersed with trypsin/EDTA and stained with annexin- $\mathrm{V}$ and deoxycarboxyfluoroscein diacetate. The number of viable, necrotic and apoptotic cells was counted and expressed as a percentage of the total.

${ }^{*} P<0 \cdot 01$ relative to untreated cells; ${ }^{* *} P<0 \cdot 001$ relative to untreated cells; ${ }^{* * *} P<0 \cdot 005$ relative to cells treated with NAF alone.

previously reported in rat islets (Loweth et al. 1996a), pretreatment with Ptx resulted in a significant potentiation of $\mathrm{NaF}-$ induced apoptosis. Genistein $(100 \mu \mathrm{M})$ was still able to increase apoptosis in human islets exposed to Ptx and, by contrast with the situation in RINm5F cells, the

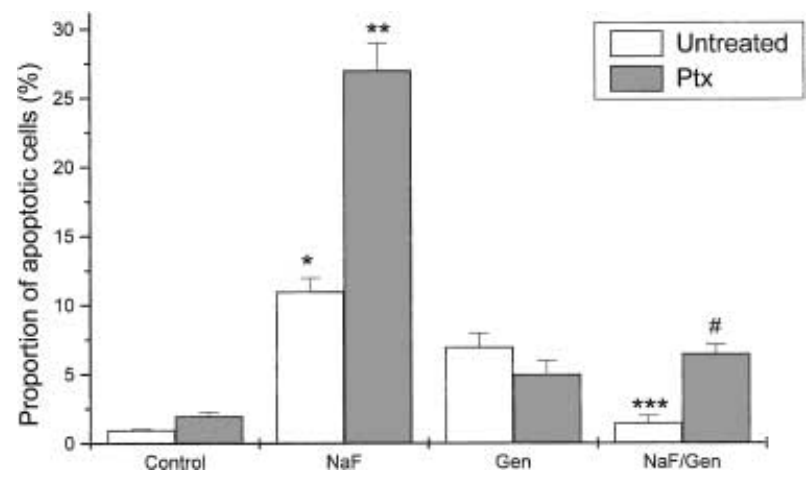

Figure 3 Effects of Ptx on apoptosis induced by $5 \mathrm{mM} \mathrm{NaF}$ and $100 \mu \mathrm{M}$ genistein in RINm5F cells. RINm5F cells were exposed to $5 \mathrm{mM} \mathrm{NaF}$ or/and $100 \mu \mathrm{M}$ genistein (Gen), as shown, for $24 \mathrm{~h}$. After this time the cells were harvested and stained with annexin- $V$ and deoxycarboxyfluoroscein diacetate. The number of apoptotic cells was counted and expressed as a proportion of the total cell number. ${ }^{*} P<0.001$ relative to untreated cells, ${ }^{* *} P<0 \cdot 001$ relative to $\mathrm{NaF}$ in the absence of $\mathrm{Ptx},{ }^{* *} P<0.005$ relative to $\mathrm{NaF}$ in the absence of genistein, $\# P<0.005$ relative to $\mathrm{NaF}$ plus Ptx in the absence of genistein. Values are means \pm S.E.M. combination of $5 \mathrm{mM} \mathrm{NaF}$ and $100 \mu \mathrm{M}$ genistein also elicited a marked increase in apoptosis under these conditions (Fig. 4). However, when the concentration of genistein was reduced to $25 \mu \mathrm{M}$, the enhancement of $\mathrm{NaF}-$ mediated apoptosis by Ptx was entirely prevented (Fig. 5).

\section{Discussion}

In each of the experimental preparations used in the present work (rat islets, human islets and RINm5F cells), exposure to either $5 \mathrm{mM} \mathrm{NaF}$ or $100 \mu \mathrm{M}$ genistein caused a significant loss of cell viability. Annexin- $\mathrm{V}$ and carboxyfluoroscein staining confirmed that this was due principally to an increase in apoptosis and revealed that the number of necrotic cells was increased to only a minor extent. The concordance of these results suggests that human islets, rat islets and RINm5F cells responded to treatment with $5 \mathrm{mM} \mathrm{NaF}$ or $100 \mu \mathrm{M}$ genistein alone, in a broadly similar manner.

Previous studies have indicated that the ability of $\mathrm{NaF}$ to promote islet cell apoptosis is mediated, at least in part, by a G-protein-dependent mechanism since the effect is attenuated by the aluminium chelator, desferrioxamine, an agent known to deplete the levels of [aluminium tetrafluoride $]^{-}$required for activation of $\mathrm{G}$-proteins by $\mathrm{NaF}$ (Loweth et al. 1996a). This is consistent with other 


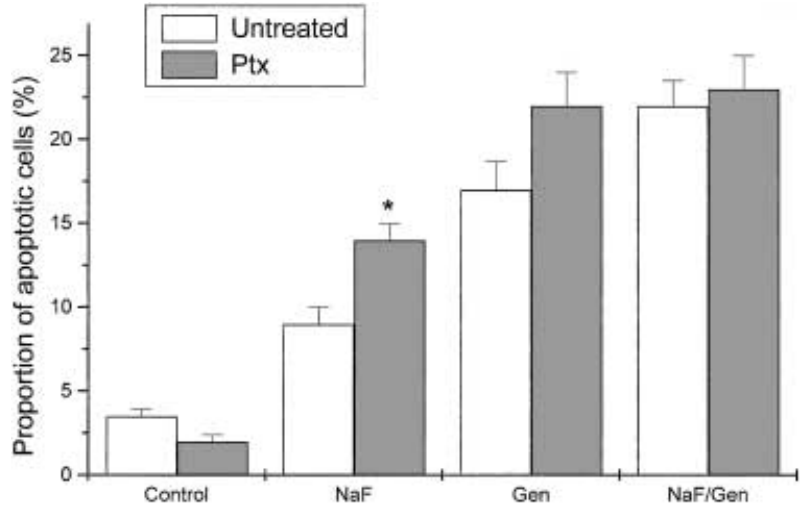

Figure 4 Effects of Ptx on apoptosis induced by $5 \mathrm{mM} \mathrm{NaF}$ and $100 \mu \mathrm{M}$ genistein in human islets. Isolated human islets were exposed to $5 \mathrm{mM} \mathrm{NaF}$ or/and $100 \mu \mathrm{M}$ genistein (Gen), as shown, for $24 \mathrm{~h}$. After this time the islets were harvested and dispersed into single cells with trypsin/EDTA. The cells were stained with annexin- $\mathrm{V}$ and deoxycarboxyfluoroscein diacetate and the number of apoptotic cells was counted and expressed as a proportion of the total cell number. ${ }^{*} P<0.01$ relative to $\mathrm{NaF}$ in the absence of Ptx. Values are means \pm S.E.M

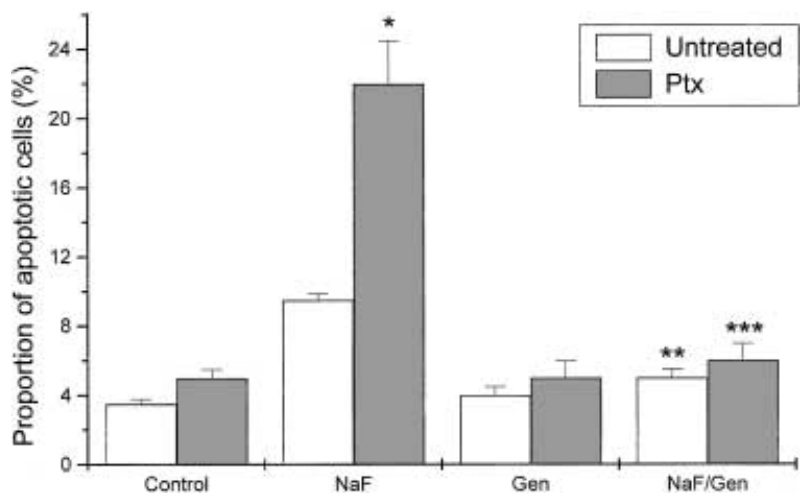

Figure 5 Effects of Ptx on apoptosis induced by $5 \mathrm{mM} \mathrm{NaF}$ and $25 \mu \mathrm{M}$ genistein in human islets. Isolated human islets were exposed to $5 \mathrm{mM} \mathrm{NaF}$ or/and $25 \mu \mathrm{M}$ genistein (Gen), as shown, for $24 \mathrm{~h}$. After this time the islets were harvested and dispersed into single cells with trypsin/EDTA. The cells were stained with annexin- $V$ and deoxycarboxyfluoroscein diacetate and the number of apoptotic cells was counted and expressed as a proportion of the total cell number. ${ }^{*} P<0 \cdot 001$ relative to $\mathrm{NaF}$ in the absence of $\mathrm{Ptx}, * * P<0 \cdot 05$ relative to $\mathrm{NaF}$ in the absence of genistein and $\mathrm{Ptx}$, ${ }^{* * *} P<0.001$ relative to $\mathrm{NaF}$ plus $\mathrm{Ptx}$ in the absence of genistein. Values are means \pm S.E.M.

emerging evidence implicating G-protein-dependent mechanisms in the control of $\beta$-cell apoptosis (Kowluru \& Morgan 2001) but does not exclude the possibility that other, less specific, effects of $\mathrm{NaF}$ may also contribute to the response.

Since genistein is a potent inhibitor of certain tyrosine kinase enzymes (Akiyama et al. 1987) the observation that $100 \mu \mathrm{M}$ genistein promotes the apoptosis of primary islet cells might indicate that the regulation of $\beta$-cell survival involves the control of a critical tyrosine kinase activity.
Indeed, evidence from other studies is consistent with this possibility (Mabley et al. 1997, Harrison et al. 1998, Zhang et al. 1998, Welsh et al. 2000). However, recent results have suggested that the pro-apoptotic effects of $100 \mu \mathrm{M}$ gensitein are more likely to be caused by inhibition of topoisomerase II than tyrosine kinase, since its effects are blocked by agents interacting with topoisomerase II (Elsea et al. 1997, Elliott et al. 2001). In confirmation of this, the present studies show that exposure of human islets to a lower concentration of genistein $(25 \mu \mathrm{M})$ did not cause an increase in apoptosis despite the fact that genistein would be expected to inhibit tyrosine kinases under these conditions (Elliott et al. 2001). Hence, any deductions about the involvement of a genistein-sensitive tyrosine kinase in the maintenance of the basal level of viability in islet cells should be made with caution. By contrast, it may reasonably be concluded that the pro-apoptotic effect of $\mathrm{NaF}$ in both RINm5F cells and human islets involves the activation of a genistein-sensitive tyrosine kinase since, in both cases, the response to $\mathrm{NaF}$ was significantly attenuated in cells treated with $25 \mu \mathrm{M}$ genistein. In an attempt to confirm this directly, we examined the extent of protein tyrosine phosphorylation under these conditions (with anti-phosphotyrosine antisera) but were not able to detect any specific changes. This may be because the critical substrate represents only a minor component of the total complement of tyrosine phosphorylated proteins within the $\beta$-cell.

In these respects, the effects seen in normal human islets were very similar to those found in RINm5F cells. However, when higher concentrations of genistein were employed in combination with $5 \mathrm{mM} \mathrm{NaF}$, the responses of human islets and RINm5F cells diverged markedly. Whereas exposure of RINm5F cells to $5 \mathrm{mM} \mathrm{NaF}$ and $100 \mu \mathrm{M}$ genistein led to attenuation of apoptosis, these agents caused an additional increase in the apoptotic death of human islet cells. This was not due to the species difference since normal rat islets responded in a similar manner to human islets. It seems likely, therefore, that the fully differentiated cells present in normal islets are more sensitive to the non-tyrosine kinase-mediated actions of genistein (e.g. inhibition of topoisomerase II) than the insulinoma-derived RINm5F cells. In support of this, the extent of apoptosis induced by exposure to $100 \mu \mathrm{M}$ genistein alone was much greater in both rat and human islets (up to $25 \%$ of the total cell population within $24 \mathrm{~h}$ ) than that found in cultures of RINm5F cells $(<10 \%$ of the population in $24 \mathrm{~h}$ ).

To clarify these issues further, both RINm5F cells and normal islets were treated with Ptx and the responses compared. Ptx has been shown to potentiate apoptosis in RINm5F cells exposed to a number of different agents (including $\mathrm{NaF}$, interleukin- $1 \beta$ and chemical nitric oxide donors) suggesting that, in these cells, a Gi/Go-dependent pathway operates to limit the effectiveness of certain pro-apoptotic stimuli (Elliott et al. 2001). A similar 
Table 3 Similarities and differences between the apoptotic responses of RINm5F cells and normal islets to fluoride, genistein and Ptx

\section{Similarities between normal islets and RINm5F cells}

Fluoride ( $5 \mathrm{mM}$ ) markedly increases apoptosis in RINm5F cells as well as in human and rat islets, consistent with the presence of a G-protein-dependent pathway regulating apoptosis.

Fluoride-induced apoptosis is attenuated by $25 \mu \mathrm{M}$ genistein in both RINm5F cells and normal islets, implying the involvement of a tyrosine kinase in the pro-apoptotic action of fluoride.

Fluoride-induced apoptosis is enhanced by Ptx in both RINm5F cells and normal islets. This response is attenuated by $25 \mu \mathrm{M}$ genistein, suggesting that a Ptx-sensitive G-protein normally opposes the pro-apoptotic effects of tyrosine kinase activation.

A high concentration of genistein $(100 \mu \mathrm{M})$ increases apoptosis in RINm5F cells and normal islets. This is unlikely to be mediated by a change in the activity of a tyrosine kinase but probably reflects inhibition of topoisomerase II.

\section{Differences between normal islets and RIN5F cells}

Upon exposure to $100 \mu \mathrm{M}$ genistein alone, the proportion of cells entering apoptosis is much greater in islets than in RINm5F cells. This is consistent with a differential sensitivity to inhibition of topoisomerase II.

Fluoride-induced apoptosis is attenuated by $100 \mu \mathrm{M}$ genistein in RINm5F cells but is further increased in rat and human islets.

The enhancement of fluoride-induced apoptosis by Ptx is blocked by $100 \mu \mathrm{M}$ genistein in RINm5F cells but not in islets.

The differential responses to genistein seen in islets and RINm5F cells suggest that the interactions between tyrosine kinase- and topoisomerase II-mediated apoptotic pathways are quite different in clonal $\beta$-cells compared with normal islets. response is evident in isolated rat islets of Langerhans (Loweth et al. 1996a) and the present work reveals that this mechanism also operates in human islets.

An important difference was revealed when RINm5F cells or primary islets were treated with Ptx then exposed to the combination of $\mathrm{NaF}$ and $100 \mu \mathrm{M}$ genistein. In RINm5F cells, the enhancing effect of Ptx on apoptosis was blocked under these conditions whereas this was not the case in islets. These observations reveal that important differences exist in RINm5F cells and normal islets, between the interactions of the pro-apoptotic pathway regulated by fluoride and that activated by a high concentration of genistein.

A lower concentration of genistein $(25 \mu \mathrm{M}$; sufficient to inhibit tyrosine kinase activity but not topoisomerase II; Elliott et al. 2001) prevented the enhancement of apoptosis caused by $\mathrm{NaF}$ and Ptx in both human islets and RINm5F cells. This confirms that human and rat $\beta$-cells each express a genistein-sensitive tyrosine kinase that is proapoptotic and whose effects are subject to regulation by a Ptx-sensitive G-protein. In drawing this conclusion, it is also important to note that Ptx did not cause any loss of viability in the absence of an apoptotic stimulus in either human islets or RINm5F cells. This implies that the Gi/Go-dependent anti-apoptotic pathway operates most effectively under conditions when apoptosis is actively promoted and that it is not required to maintain islet cell viability under resting conditions.

When considering the overall implications of the current results, it should be borne in mind that, unlike RINm5F cells, rat and human islets are not homogeneous populations of insulin-secreting $\beta$-cells. Hence, it is possible that variations in the responses of the individual cell types could have influenced the results obtained. However, this explanation is unlikely to account completely for the differences observed, since whole islets and RINm5F cells responded to $\mathrm{NaF}$, genistein and Ptx in a broadly similar manner under most circumstances and only displayed markedly divergent responses when the stimuli were combined. This, in turn, suggests that the most striking differences occur in the mechanisms regulating aspects of 'cross-talk' between the various pathways involved in the control of apoptosis in $\beta$-cells.

In conclusion, therefore, the results obtained in this work imply that, although there are a considerable number of similarities between the responses of RINm5F and normal islet cells to defined apoptotic stimuli, conditions exist under which significant differences are seen. The principal similarities and differences between the apoptotic responses to $\mathrm{NaF}$, genistein and Ptx are summarised in Table 3. The results emphasise that conclusions drawn about the regulation of apoptosis in cultured RINm5F cells exposed to pharmacological agents should be confirmed with cells from normal islets before direct extrapolations are made from one to the other.

\section{Acknowledgements}

We thank Scotia Pharmaceuticals and Diabetes UK for financial support of this work and Dr A Kowluru for helpful comments and discussion.

\section{References}

Ahmad M, Flatt PR, Furman BL \& Pyne NJ 2000 The role of cyclic GMP-inhibited cyclic AMP-specific phosphodiesterase (PDE3) in regulating clonal BRIN-BD11 insulin secreting cell survival. Cell Signalling 12 541-548.

Akiyama T, Ishida J, Nakagawa S, Ogawara $\mathrm{H}$, Watanabe S, Itoh N, Shibuya M \& Fukami Y 1987 Genistein, a specific inhibitor of tyrosine specific kinases. Journal of Biological Chemistry 262 592-595. 
Ammendrup A, Maillard A, Nielsen K, Aabenhus-Andersen N, Serup P, Dragsbaek-Madsen O, Mandrup-Poulsen T \& Bonny C 2000 The c-Jun amino-terminal kinase pathway is preferentially activated by interleukin-1 and controls apoptosis in differentiating pancreatic beta cells. Diabetes 49 1468-1476.

Bai JZ, Saafi EL, Zhang S \& Cooper GJ 1999 Role of $\mathrm{Ca}^{2+}$ in apoptosis evoked by human amylin in pancreatic islet $\beta$-cells. Biochemical Journal 343 53-61.

Baker MS, Chen X, Cao XC \& Kaufman DB 2001 Expression of dominant negative inhibitor of NF-kappaB protects MIN6 beta cells from cytokine-induced apoptosis. Journal of Surgical Research $\mathbf{9 7}$ 117-122.

Bonny C, Oberson A, Negri S, Sauser C \& Schorderet DF 2001 Cell-permeable inhibitors of JNK: novel blockers of beta cell death. Diabetes 50 77-82.

Di Matteo MA, Loweth AC, Thomas S, Mabley JG, Morgan NG, Thorpe JR \& Green IC 1997 Superoxide, nitric oxide, peroxynitrite and cytokine combinations all cause functional impairment and morphological changes in rat islets of Langerhans and insulin secreting cell lines, but dictate cell death by different mechanisms. Apoptosis 2 164-177.

Elliott J, Scarpello JHB \& Morgan NG 2001 Effects of tyrosine kinase inhibitors on cell death induced by sodium fluoride and pertussis toxin in the pancreatic $\beta$-cell line, RINm5F. British Journal of Pharmacology 132 119-126.

Elsea SH, Westergaard M, Burden DA, Lomenick JP \& Osheroff N 1997 Quinolones share a common interaction domain on topoisomerase II with other DNA cleavage-enhancing antineoplastic drugs. Biochemistry 36 2919-2924.

Gazdar AF, Chick WL, Oie HK, Sims HL, King DL, Weir GC \& Lauris V 1980 Continuous, clonal, insulin- and somatostatinsecreting cell lines established from a transplantable rat islet cell tumor. PNAS 77 3519-3523.

Harrison M, Dunger AM, Berg S, Mabley J, John N, Green MH \& Green IC 1998 Growth factor protection against cytokine-induced apoptosis in neonatal rat islets of Langerhans: role of Fas. FEBS Letters 435 207-210.

Jonas JC, Plant TD, Gilon P, Detimary P, Nenquin M \& Henquin JC 1995 Multiple effects and stimulation of insulin secretion by the tyrosine kinase inhibitor genistein in normal mouse islets. British Journal of Pharmacology 114 872-880.

Kowluru A \& Morgan NG 2001 GTP-binding proteins in cell survival and demise: the emerging picture in the pancreatic $\beta$-cell. Biochemical Pharmacology (In Press).

Krautheim A, Brechlin P, Becker K, Winkler M \& Steinfelder HJ 2000 Hamster pancreatic $\beta$-cell lines with altered sensitivity to apoptotic signalling by phosphatase inhibitors. British Journal of Pharmacology 129 687-694.

Kwon G, Corbett JA, Rodi CP, Sullivan P \& McDaniel ML 1995 Interleukin-1 $\beta$-induced nitric oxide synthase expression by rat pancreatic beta cells: evidence for the involvement of nuclear factor kappa B in the signaling mechanism. Endocrinology 136 4790-4795.

Lacey RJ, Berrow NS, London NJM, Lake SP, James RF, Scarpello JHB \& Morgan NG 1990 Differential effects of $\beta$-adrenergic agonists on insulin secretion from pancreatic islets isolated from rat and man. Journal of Molecular Endocrinology 5 49-54.

Lacey RJ, Cable HC, James RF, London NJM, Scarpello JHB \& Morgan NG 1993 Concentration-dependent effects of adrenaline on the profile of insulin secretion from isolated human islets of Langerhans. Journal of Endocrinology 138 555-563.

Loweth AC, Williams GT, Scarpello JHB \& Morgan NG $1996 a$ Heterotrimeric G-proteins are implicated in the regulation of apoptosis in pancreatic $\beta$-cells. Experimental Cell Research 229 69-76.

Loweth AC, Williams GT, Scarpello JHB, James RFL \& Morgan NG $1996 b$ Human pancreatic islets display reduced sensitivity to nitric oxide-induced apoptosis compared to rodent clonal B-cell lines. Diabetes Research 31 231-241.

Loweth AC, Williams GT, Scarpello JHB \& Morgan NG 1997 Evidence for the involvement of cGMP and protein kinase $G$ in nitric oxide-induced apoptosis in the pancreatic $\beta$-cell line, HIT-T15. FEBS Letters 400 285-288.

Loweth AC, Williams GT, James RFL, Scarpello JHB \& Morgan NG 1998 Human islets of Langerhans express Fas-Ligand and undergo apoptosis in response to interleukin-1 $\beta$ and Fas ligation. Diabetes 47 727-732.

Mabley JG, Belin V, John N \& Green IC 1997 Insulin-like growth factor-1 reverses interleukin- $1 \beta$ inhibition of insulin secretion, induction of nitric oxide synthase and cytokine mediated apoptosis in rat islets of Langerhans. FEBS Letters 417 235-238.

Mandrup-Poulsen T 2001 Beta cell apoptosis: stimuli and signalling. Diabetes 50 S58-S63.

Mauricio D \& Mandrup-Poulsen T 1998 Apoptosis and the pathogenesis of IDDM: a question of life and death. Diabetes $\mathbf{4 7}$ 1537-1543.

Mitchell CJ, Kelly MM, Blewitt M, Wilson JR \& Biden TJ 2001 Phospholipase $\mathrm{C} \gamma$ mediates the hydrolysis of phosphatidylinositol, but not phosphatidylinositol 4,5-bisphosphate, in carbamylcholinestimulated islets of Langerhans. Journal of Biological Chemistry 276 19072-19077.

Mountz JD, Zhang HG, Hsu HC, Fleck M, Wu J al-Maini MH \& Zhou T 1999 Apoptosis and cell death in the endocrine system. Recent Progress in Hormone Research 54 235-268.

Nakata M, Uto N, Maruyama I \& Yada T 1999 Nitric oxide induces apoptosis via $\mathrm{Ca}^{2+}$-dependent processes in the pancreatic beta cell line MIN6. Cell Structure and Function 24 451-455.

Olejnicka BT, Dalen H \& Brunk UT 1999 Minute oxidative stress is sufficient to induce apoptotic death in NIT-1 insulinoma cells. APMIS 107 747-761.

Roche E, Maestre I, Martin F, Fuentes E, Casero J, Reig JA \& Soria B 2000 Nutrient toxicity in pancreatic beta cell dysfunction. Journal of Physiology and Biochemistry 56 119-128.

Signore A, Annovazzi A, Gradini R, Liddi R \& Ruberti G 1998 Fas and Fas-Ligand-mediated apoptosis and its role in autoimmune diabetes. Diabetes/Metabolism Reviews 14 197-206.

Sjoholm A 1998 Aspects of the involvement of interleukin-1 and nitric oxide in the pathogenesis of insulin-dependent diabetes mellitus. Cell Death and Differentiation 5 461-468.

Sjoholm A, Berggren P-O \& Cooney RV 2000 Gamma-tocopherol partially protects insulin-secreting cells against inhibition by nitric oxide. Biochemical and Biophysical Research Communications 277 334-340.

Sorenson RL, Brejle TC \& Roth C 1994 Effect of tyrosine kinase inhibitors on islets of Langerhans: evidence for tyrosine kinases in the regulation of insulin secretion. Endocrinology 134 1975-1978.

Tejedo J, Bernabe JC, Ramirez R, Sobrino F \& Bedoya FJ 1999 NO induces a cGMP-independent release of cytochrome $\mathrm{c}$ from mitochondria which precedes caspase 3 activation in insulin producing RINm5F cells. FEBS Letters 459 238-243.

Welsh M, Anneren C, Lindholm C, Kriz V \& Oberg-Welsh C 2000 Role of tyrosine kinase signaling for $\beta$-cell replication and survival. Uppsala Journal of Medical Sciences 105 7-15.

Zhang Q, Berggren P-O, Hansson A \& Tally M 1998 Insulin-like growth factor 1-induced DNA synthesis in insulin secreting cell line RINm5F is associated with phosphorylation of the insulin-like growth factor 1 receptor and the insulin receptor substrate 2. Journal of Endocrinology 156 573-581.

Received 23 July 2001

Accepted 19 September 2001 